\title{
The impact of intra-operative cell salvage during open radical prostatectomy
}

\author{
Ned Kinnear ${ }^{1}$, Bridget Heijkoop ${ }^{1}$, Lina Hua ${ }^{1}$, Derek B. Hennessey ${ }^{2}$, Daniel Spernat ${ }^{1}$ \\ ${ }^{1}$ Department of Urology, The Queen Elizabeth Hospital, Adelaide, Australia; ${ }^{2}$ Department of Urology, Craigavon Area Hospital, Portadown, UK \\ Contributions: (I) Conception and design: N Kinnear; (II) Administrative support: N Kinnear, B Heijkoop, L Hua; (III) Provision of study material or \\ patients: N Kinnear, B Heijkoop, L Hua; (IV) Collection and assembly of data: N Kinnear, B Heijkoop, L Hua; (V) Data analysis and interpretation: \\ N Kinnear, DB Hennessey, D Spernat; (VI) Manuscript writing: All authors; (VII) Final approval of manuscript: All authors. \\ Correspondence to: Dr. Ned Kinnear. The Queen Elizabeth Hospital, 28 Woodville Rd, Woodville South, SA 5011, Australia. \\ Email: ned.kinnear@gmail.com.
}

Background: To examine the effect of intra-operative cell salvage (ICS) in open radical prostatectomy. Methods: In this retrospective cohort study, all patients undergoing open radical prostatectomy for malignancy at our institution between 10/04/2013 and 10/04/2017 were enrolled. Patients were grouped and compared based on whether they received ICS. Primary outcomes were allogeneic transfusion rates, and disease recurrence. Secondary outcomes were complications and transfusion-related cost.

Results: Fifty-nine men were enrolled; 30 used no blood conservation technique, while 29 employed ICS. There were no significant differences between groups in age, pre- or post-operative haemoglobin, Charlson comorbidity index, operation duration or length of stay. Tumour characteristics were also similar between groups, including pre-operative prostate specific antigen, post-operative Gleason score, T-stage, nodal status and rates of margin positivity. Compared with controls, the ICS group had longer follow up (945 vs. 989 days; $\mathrm{P}=0.0016)$. The control and ICS groups were not significantly different in rates of tumour recurrence (6 vs. 3 patients; $\mathrm{P}=0.30$ ) or complications (10 vs. 5 patients; $\mathrm{P}=0.16$ ). While the proportion of patients receiving allogenic transfusion was similar ( 9 vs. 6 patients; $\mathrm{P}=0.41$ ), fewer red blood products transfused (40 vs. 12 units) meant transfusion related costs were lower in ICS patients (AUD \$47,666 vs. \$37,429).

Conclusions: ICS reduced transfusion related costs, without affecting allogeneic transfusion rates, tumour recurrence or complication rates. These findings extend the literature supporting ICS in oncological surgery. Prospective randomised studies are needed to confirm the existing level III evidence.

Keywords: Prostatectomy; cell salvage; autologous; transfusion; blood; cost

Submitted Apr 11, 2018. Accepted for publication Apr 16, 2018.

doi: 10.21037/tau.2018.04.19

View this article at: http://dx.doi.org/10.21037/tau.2018.04.19

\section{Introduction}

Amongst men, prostate cancer is the most common noncutaneous cancer and the second leading cause of cancer death (1). Annually in the United States of America (USA), $>240,000$ men are diagnosed with prostate cancer, with approximately one third undergoing radical prostatectomy $(1,2)$. Operative blood loss has fallen steadily, due to the combined effects of greater understanding of the vasculature, improved technique, more sophisticated cautery technology and the introduction of minimally invasive approaches $(3,4)$. Despite this, transfusion rates for open radical prostatectomy remain high, at 4-14\% $(3,5-8)$. While mature blood banks have made allogeneic transfusion easily accessible and relatively safe, it still carries significant challenges including bacterial and viral transmission, transfusion reactions, tumour recurrence, cost and availability. The overall risk of any adverse event is 77 per 100,000 red blood cell (RBC) transfusions, and death in 1 per 100,000 (9). Studies of $>26,000$ patients report 
allogeneic, but not autologous, transfusion to be associated with worse oncological outcomes, due to transfusion related immunomodulation (10-12). The supply and administration costs of a single RBC unit continues to increase, with current pricing ranging USD \$600-\$1,000 $(13,14)$.

Intra-operative cell salvage (ICS) is a growing blood conservation technique involving the reinfusion of lost blood. Blood spilled in the operative field is collected, anticoagulated, washed, concentrated, filtered and returned to the patient. Reinfusion may occur intra-operatively, or up to four hours post operatively. ICS is safe and effective. Three large audits of 18,000-64,000 units of reinfused salvaged blood report complication rates of $<0.027 \%(15-17)$. Several studies including a Cochrane review have demonstrated ICS reduces allogeneic transfusion rates (ATR) by over a third (18-22). ICS avoids most of the risks of allogeneic transfusion, and has been demonstrated to be more cost effective (23).

Due to fears of potential reinfusion of tumour cells, ICS was initially thought contra-indicated during cancer surgery. However, a wealth of studies have since found oncological outcomes for ICS patients to be equivalent or even superior to those receiving allogeneic transfusion (20,22,24-34). To date, the literature on ICS in radical prostatectomy consists of eleven cohort studies from the United Kingdom and USA (20-22,26-33,35-37). However, the majority compared ICS to pre-operative autologous donation (PAD) $(20,26,30,32,35-37)$, a technique now seldom used. Additionally, the use ICS in uro-oncology in the Southern hemisphere has not been examined. Therefore, we aim to compare the outcomes of patients who did and did not receive ICS while undergoing open radical prostatectomy.

\section{Methods}

A retrospective cohort study was performed, enrolling all patients undergoing open radical prostatectomy at our institution between 10/04/2013 and 10/04/2017. Data were collected from hospital electronic and hard copy records. All patients underwent surveillance for tumour recurrence, according to the National Comprehensive Cancer Network (NCCN) post-prostatectomy surveillance guidelines (38). Per NCCN criteria, disease recurrence post prostatectomy was defined as either failure of PSA to fall to undetectable levels, or undetectable PSA followed by PSA detectable and rising on two consecutive measurements (38).

Patients who did (ICS group) and did not (control group) receive ICS were compared. Primary outcomes were ATR and disease recurrence. Secondary outcomes were complications and transfusion-related cost. Complications were categorised based on the Clavien-Dindo grading system (39). Ethics approval was granted by the Central Adelaide Local Health Network human research ethics committee, reference HREC/17/TQEH/255.

\section{ICS practice}

Our institution commenced using ICS for open radical prostatectomy in September 2014. Usage was initially intermittent, reserved for cases deemed high bleeding risk, until following departmental review of evidence in December 2016 it was decided to employ ICS routinely, allowing for surgeon preference. We use the Fresenius Kabi CATSmart Continuous Autotransfusion System ${ }^{\mathrm{TM}}$, with a Haemonectics ${ }^{\mathrm{TM}}$ RS1VAE leucocyte depletion filter. As recommended by several authors $(25,37)$, we use ICS in a financially tiered system. For all cases utilizing ICS, anticoagulated salvaged blood is collected in a reservoir (basic setup). When desired, this blood is processed and reinfused (reinfusion setup). Thus, the ICS processor set and other items are not wasted when blood is not reinfused.

The transfusion trigger is decided by the anaesthetist, based on patient pre-operative haemoglobin, cardiorespiratory comorbidities, volume of blood collected, ongoing haemorrhage, intra-operative heart rate and blood pressure.

\section{Transfusion related cost calculations}

All costs were calculated as of 30/06/17. Transfusion related costs were calculated as allogeneic transfusion cost + ICS setup cost + ICS reinfusion cost. Costs related to length of stay and complications were not included.

Allogeneic transfusion costs include both the product and process. The product cost of one RBC unit at our institution is \$412.66 Australian Dollars (AUD), purchased from the National Blood Authority, Australia (40). Process costs of transfusion, including in-hospital logistics, blood tests, staffing and overhead expenses, are known to be three to five times higher than the product cost $(13,14)$. The first estimate of process costs in Australia by Wood et al. in 2006 of AUD \$370 per unit RBC infused (41) were updated in 2010 to AUD \$536 using the Australian Bureau of Statistics consumer price index for hospital and medical services (42). Utilising the same method translated to a subsequent $45.3 \%$ increase from end-of-financial-year 2010 to 2017 (43), giving a current process cost of AUD \$779, and a total cost per RBC unit infused of AUD \$1,191.66. 
Table 1 The cost of intra-operative cell salvage set up and reinfusion in Australian dollars, as of 30 June 2017

\begin{tabular}{ll}
\hline Item & Cost \\
\hline $\begin{array}{l}\text { Sub-total, intra-operative cell salvage (ICS) } \\
\text { setup cost }\end{array}$ & $\$ 586.80$ \\
Separate Yanker sucker & \\
Dual lumen sucker line & $\$ 0.98$ \\
Anticoagulant; 2 ampoules of 25,000 units/ & $\$ 27.50$ \\
5 mL heparin & $\$ 12.64$ \\
ICS machine tubing & \\
1×1,000 mL 0.9\% normal saline & $\$ 2.13$ \\
ICS reservoir & $\$ 1.10$ \\
Bacterial filter & $\$ 72.50$ \\
Anaesthetic nurse wages per case & $\$ 4.54$ \\
Sub-total, ICS reinfusion cost & $\$ 465.41$ \\
Leucocyte depletion filter; Haemonectics ${ }^{\mathrm{TM}}$ & $\$ 382.00$ \\
RS1VAE & $\$ 56.00$ \\
ICS processor set & $\$ 280.00$ \\
Reinfusion bag & $\$ 35.00$ \\
10×1,000 mL 0.9\% normal saline per $500 \mathrm{~mL}$ & $\$ 11.00$ \\
\hline reinfused at $\$ 1.10 /$ bag & \\
\hline
\end{tabular}

ICS costs were calculated by pricing every item involved, and also service-specific staffing. Staffing costs represent the majority of the ICS setup cost. The machine is run by one of several dedicated ICS-trained in-house year $\geq 9$ anaesthetic nurses. When ICS is requested, our practice is to roster an additional anaesthetic nurse to liberate one whom is ICS trained. Due to a limited in-house staffing pool, it is often necessary to hire an agency nurse for this purpose. Current pricing in our institution for an in-house year $\geq 9$ anaesthetic nurse is AUD $\$ 42.28$ per hour for a set eight hour shift, and for an equivalent agency nurse AUD \$77 per hour for a flexible duration shift. Of the 29 ICS cases, 16 utilised in-house nurse cover totalling 128 hours, while for 13 an agency nurse was employed for 105 hours in all. This represented an ICS staffing cost of $\$ 13,496.84$ total, or $\$ 465.41$ per case. Incorporating equipment costs (Table 1), ICS setup cost was AUD $\$ 586.80$ per case, with reinfusion an additional AUD \$382.00 per case.

\section{Statistical analysis}

Continuous data were summarized as medians with interquartile range (IQR), and significance assessed using the Wilcoxon (Mann-Whitney) test. Categorical measures were summarized as proportions and assessed with Pearson's chi-square test. All tests were two-tailed and significance was assessed at the $5 \%$ alpha level. Data were analysed using SAS v9.3 (SAS Institute Inc., Cary, NC, USA).

\section{Results}

\section{Demographics}

59 men underwent open radical prostatectomy during the enrolment period. 30 patients did not utilise ICS (control group), while 29 did (ICS group). There was no statistical difference between groups' median age (62.5 vs. 65 years; $\mathrm{P}=0.28$ ), Charlson comorbidity index (4 vs. 4; $\mathrm{P}=0.32$ ) or serum haemoglobin pre- $(148 v s .151 \mathrm{~g} / \mathrm{L} ; \mathrm{P}=0.84)$ or postoperatively (102 vs. $102 \mathrm{~g} / \mathrm{L} ; \mathrm{P}=0.72$ ). Median operation duration (5.8 vs. $6.1 \mathrm{~h} ; \mathrm{P}=0.058)$ and length of stay was also comparable ( 5 vs. 5 days; $\mathrm{P}=0.73$ ). Follow up was significantly longer for the ICS group (945 vs. 989 days; $\mathrm{P}=0.0016$ ) (Table 2).

\section{Oncological characteristics}

The two groups had similar pre-operative PSA (6.7 vs. $6.8 \mathrm{ng} / \mathrm{mL} ; \mathrm{P}=0.56$ ). Histopathology of the prostatectomy specimens was also closely matched in the groups, with the most common Gleason score being $7(3+4)$, and most common pathological tumour stage being pT2c in both groups. Three controls and one ICS patient had nodal disease $(\mathrm{P}=0.32)$. No patients had evidence of metastasis at time of procedure. Surgical margins were positive in eight controls and six ICS patients $(\mathrm{P}=0.59)$ (Table 2).

\section{Primary outcomes}

There was no significant difference in tumour recurrence ( 6 vs. 3 cases; $\mathrm{P}=0.30$ ). Nine control patients received a total of 40 units of allogeneic red blood, while six ICS patients were altogether transfused twelve units. There was no significant difference in ATR $(\mathrm{P}=0.41)$.

\section{Secondary outcomes}

Complications were seen in ten control patients and five ICS patients $(\mathrm{P}=0.16)$ (Table 3). Transfusion related costs were lower in the ICS group, both overall (AUD \$47,666 
Table 2 Patient characteristics and outcomes

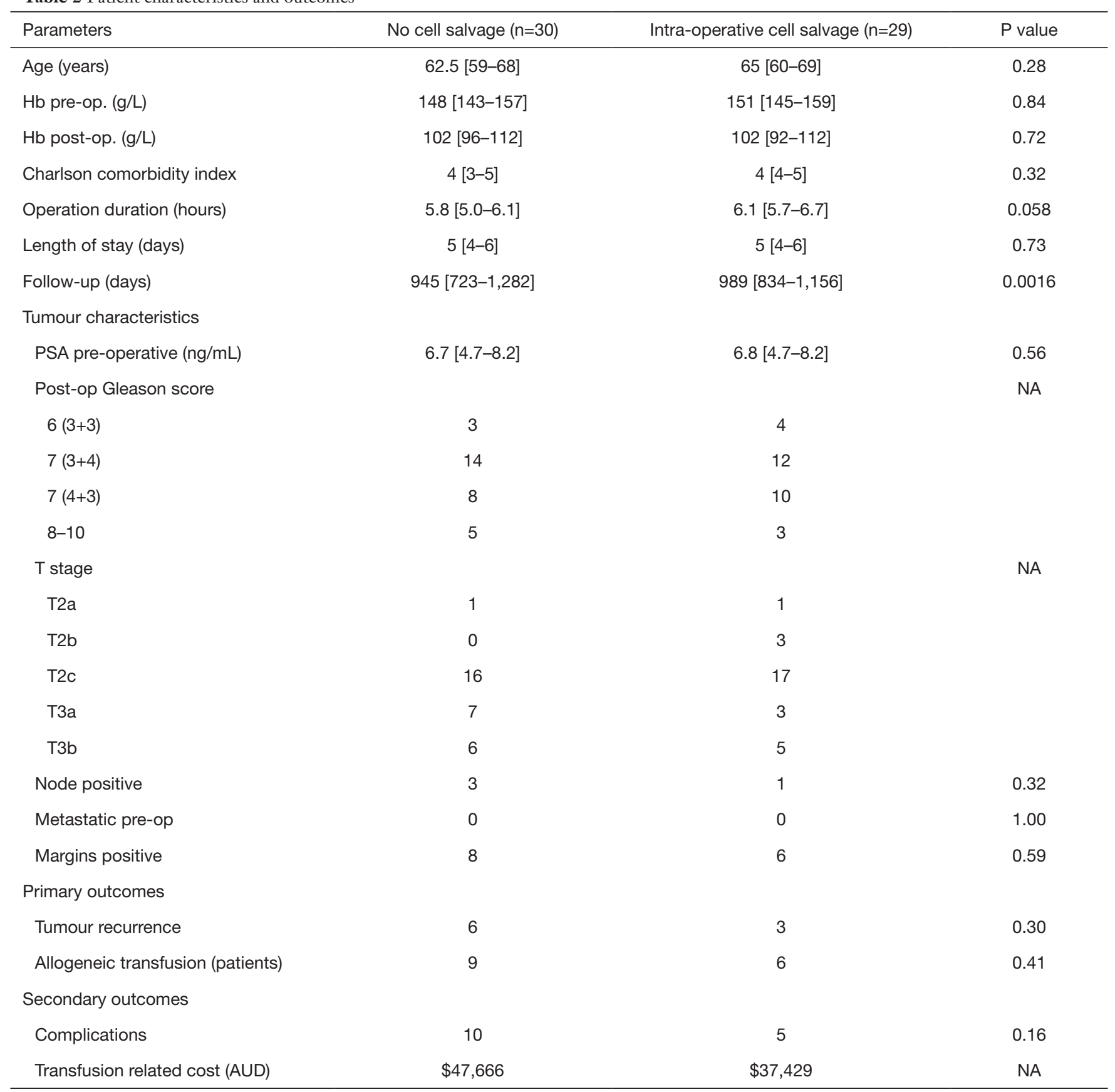

Data given as median [interquartile range]. AUD, Australian dollars; NA, not applicable.

vs. $\$ 37,429$ ) and per patient (AUD $\$ 1,589$ vs. $\$ 1,291$ ).

\section{Discussion}

First impressions can be misleading and lasting, and this has been the case for ICS in oncological surgery.
When introduced, it was feared that re-infusion of blood salvaged during tumour resection could lead to diffuse metastasis. The sole supporting evidence was a 1975 case study in which a patient with lung cancer underwent pneumonectomy utilising ICS, and died four weeks later with diffuse metastasis (44). In 1986 the American Medical 
Table 3 Complications

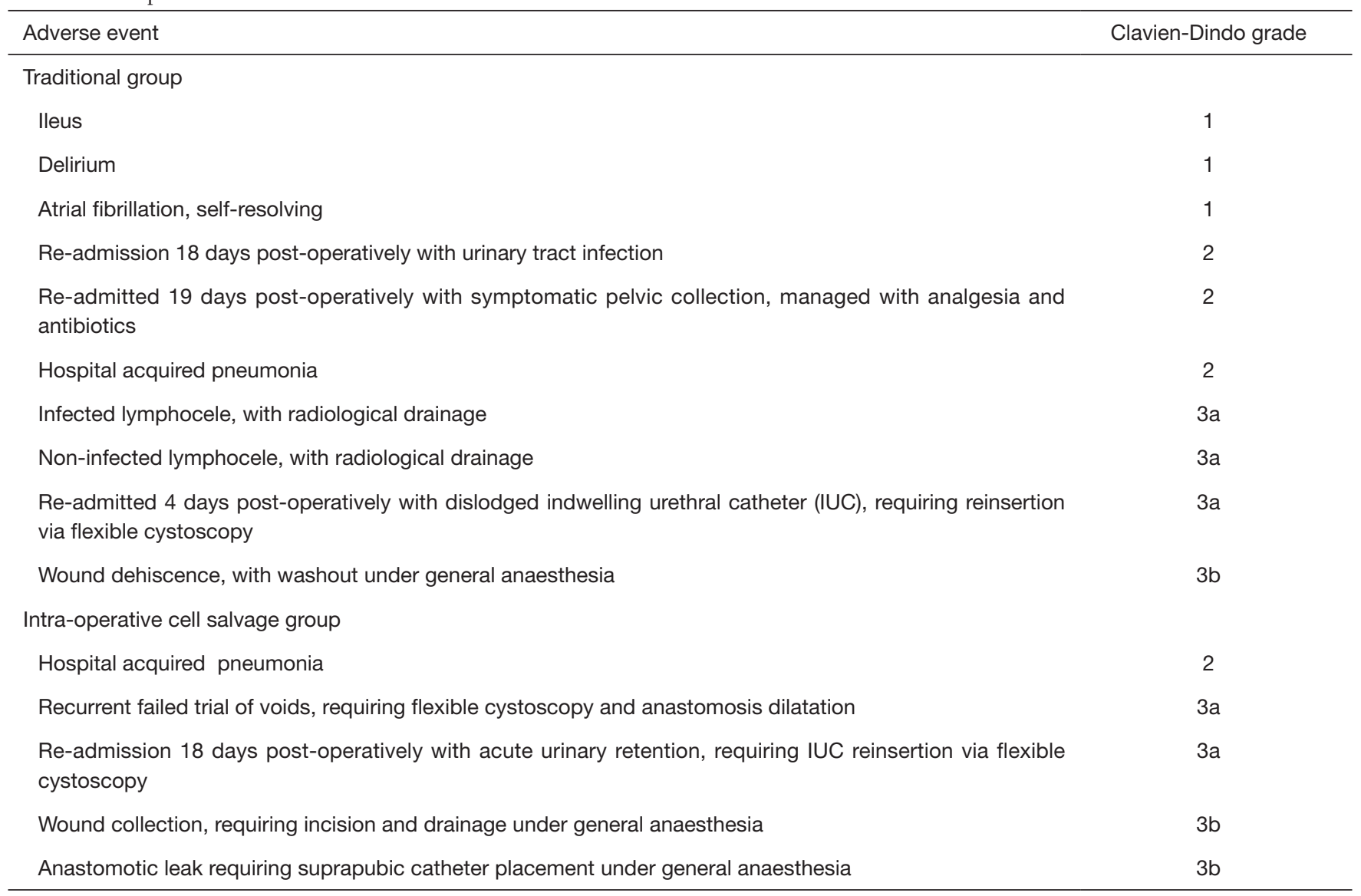

Association Council on Scientific Affairs recommended against the use of ICS during tumour resection (45). However, there has since been a steady stream of studies demonstrating oncological safety. Subsequently, ICS use in uro-oncology and other oncological surgery has been supported by many national healthcare bodies, including the United Kingdom's National Institute for Health and Care Excellence (NICE), the Association of Anaesthetists of Great Britain and Ireland, the American Association of Blood Banks (AABB) and the National Blood Authority Australia (46-49).

Despite this broad-based institutional backing, the uptake of ICS has been slow (50) (51), due to persisting perceptions that ICS is expensive, ineffective and risks tumour recurrence. The task, then, is to objectively examine cost, efficacy and safety.

This study found that the use of ICS decreased transfusion related costs. This was despite the conservative practice of employing two anaesthetic nurses for each case; one to work alongside the anaesthetist and another to run the ICS machine. This study has led to a change in practice at our institution. In the short term, the pool of in-house anaesthetic nurses will be increased to avoid use of the more expensive agency nurses. In the longer term, a single anaesthetic nurse is planned to perform both ICS and anaesthetist-support functions, with rostering of a second nurse to be phased out altogether. Our findings of cost reductions echo recent studies of ICS during prostatectomy and cystectomy $(21,22)$. Additionally, Davies et al.'s systematic review of blood conservation economics concluded ICS to be more cost effective than allogeneic transfusion alone (23). However, some authors have found failed to find financial benefit utilising ICS $(36,52)$. Given variation between healthcare sites in models of ICS delivery and allogeneic blood cost, and between procedures in intra-operative blood loss, it is clear ICS will not be cost effective in all circumstances. The AABB recognise this, and recommend ICS use during surgery where anticipated 
blood loss is significant, specifically $>750 \mathrm{~mL},>20 \%$ of estimated blood volume, great enough to induce anaemia or leads to transfusion in $>10 \%$ of patients (49).

When employed during applicable procedures, ICS is clearly effective in avoiding transfusion. Meta-analyses including a Cochrane review of 75 non-oncological randomised controlled trials (RCTs) found ICS reduced ATR by $>38 \%(18,19)$. Amongst existing comparative prostatectomy ICS studies, while some have reported significant ATR reductions $(20,22)$, most have not $(26,27,30,32,35-37)$. This lack of effect is likely influenced by the well-documented decreasing blood loss during prostatectomy $(3,4)$ combined with underpowered studies. With reported ICS groups having median ATR of 3.3\% (standard deviation $15 \%)(20,22,26,27,30,32,35-37)$, to detect ATR one third lower than controls, prostatectomy studies using standard $80 \%$ power would need samples of 1,295 patients.

ICS safety includes both complications and tumour recurrence. The scarcity of complications from ICS use has been clearly documented (15-18). Demonstration of oncological safety is both empirical and theoretical. The ten uro-oncological comparative studies to date that report oncological outcomes all report equivalent or reduced disease recurrence $(20,22,26-33)$. Three meta-analyses of ICS in oncological surgery failed to find a single publication demonstrating worse recurrence with ICS $(19,34,53)$.

If empirical data do not demonstrate increased metastatic risk, the alternate test is to construct a realistic theoretical argument for risk. For ICS to cause metastasis, malignant cells must exist in the shed blood, be poorly removed by the ICS machine, have high malignant potential and meaningfully increase numbers of circulating tumour cells. The first of these four premises is undoubtedly true; numerous studies have found tumour cells in ICS blood $(24,54,55)$. Secondly, leucocyte depletion filters are commonly used to remove tumour cells and bacteria. Studies both clinical and in vitro have demonstrated the ability of these filters to remove $>99.9 \%$ of tumour cells $(20,24,56,57)$, with several authors finding tumour cells were completely removed (58-61). Regardless of filter, the sublethal shear stress exerted by the ICS machine on reinfused RBCs (62), at only $8 \mathrm{~mm}$ diameter, is likely to be more severe for the larger tumour cells. Filtration may be unnecessary, given most of the uro-oncological ICS studies did not use leucocyte depletion filters, with none reporting worse recurrence rates $(26-29,31,35,36)$. Third is the question of metastatic potential. While tumour cells dislodged by surgical manipulation are fresh and in vitro display metastatic characteristics (54), animal studies indicate great malignant inefficiency, with only $0.000001-0.01 \%$ of circulating tumour cells holding metastatic potential (63). Fourthly, is the reinfusion of more tumour cells significant? Several authors have shown that patients with solid organ malignancy often have circulating tumour cells pre-operatively $(64,65)$. Indeed, Glaves et al. measured patients with renal cell carcinoma releasing $37,000,000$ tumour cells into the renal vein per day (66). Reverse transcriptase serum studies performed pre-, intraand post-operatively clearly demonstrate that surgical manipulation releases additional tumour cells into the circulation $(65,67,68)$.

In summary, the theoretical model for ICS being a legitimate means of metastasis seems tenuous. While ICS does aspirate tumour cells, nearly all will be removed or destroyed by filters or the ICS machine's shear stress, most of the remainder hold no malignant potential, and those that do will be reinfused into a circulation already containing vastly more pre-existing tumour cells. We must also balance this weak theoretical argument against ICS, unsupported by many studies, with the clear clinical evidence that allogeneic transfusion increases risk of recurrence. In urology, this includes a study of $>48,000$ patients (11) and two metaanalyses $(10,69)$.

This is the first comparative study of ICS during radical prostatectomy outside the United Kingdom or the USA. It is also only the fourth comparative study of ICS in any specialty in Australia (70-72).

This study is limited by its retrospective nature, small size, non-randomised nature and short follow-up. While there were no significant differences in group demographics, selection bias may nevertheless have impacted our findings.

\section{Conclusions}

ICS reduces transfusion related costs, and does not affect tumour recurrence or complication rate. No difference in allogeneic transfusion rate was seen. This study extends the literature in support of ICS in oncological surgery. Prospective randomised studies are needed to confirm these findings.

\section{Acknowledgements}

The authors thank anaesthetist Dr. Jellsingh Jeyadoss in campaigning for routine use of ICS. We also thank 
theatre administrators Rosemary Obst, Karen Taylor and Caroline Saniotis for their help obtaining data, and also haematologists Dr. Simon McRae, Dr Ben Saxon and Dr Kathryn Robinson for their guidance in transfusion-related costing.

\section{Footnote}

Conflicts of Interest: The authors have no conflicts of interest to declare.

Ethical Statement: All procedures performed in studies involving human participants were in accordance with the ethical standards of the institutional and/or national research committee and with the 1964 Helsinki declaration and its later amendments or comparable ethical standards. For this type of retrospective study, formal consent is not required. Nevertheless, ethics approval for this study was granted by the Central Adelaide Local Health Network human research ethics committee, reference HREC/17/ TQEH/255.

\section{References}

1. Brawley OW. Prostate cancer epidemiology in the United States. World J Urol 2012;30:195-200.

2. Lowrance WT, Eastham JA, Savage C, et al. Contemporary open and robotic radical prostatectomy practice patterns among urologists in the United States. J Urol 2012;187:2087-92.

3. Moul JW, Sun L, Wu H, et al. Factors associated with blood loss during radical prostatectomy for localized prostate cancer in the prostate-specific antigen (PSA)-era: an overview of the Department of Defense (DOD) Center for Prostate Disease Research (CPDR) national database. Urol Oncol 2003;21:447-55.

4. Stav K, Rahimi-Levene N, Lindner A, et al. Retropubic radical prostatectomy: associated blood loss and transfusion requirements--a two-decade perspective review. Isr Med Assoc J 2005;7:103-6.

5. Kordan Y, Barocas DA, Altamar HO, et al. Comparison of transfusion requirements between open and roboticassisted laparoscopic radical prostatectomy. BJU Int 2010;106:1036-40.

6. Nuttall GA, Cragun MD, Hill DL, et al. Radical retropubic prostatectomy and blood transfusion. Mayo Clin Proc 2002;77:1301-5.

7. Paul R, Schmid R, Busch R, et al. Influence of blood transfusions during radical retropubic prostatectomy on disease outcome. Urology 2006;67:137-41.

8. Schmitges J, Sun M, Abdollah F, et al. Blood transfusions in radical prostatectomy: a contemporary population-based analysis. Urology 2012;79:332-8.

9. Bolton-Maggs P, Poles D. The 2016 Annual SHOT Report (2017): Serious Hazards of Transfusion; 2017 (01 September 2017). Available online: https://www.shotuk.org/wpcontent/uploads/SHOT-Report-2016_web_11th-July.pdf

10. Li SL, Ye Y, Yuan XH. Association between Allogeneic or Autologous Blood Transfusion and Survival in Patients after Radical Prostatectomy: A Systematic Review and Meta-Analysis. PLoS One 2017;12:e0171081.

11. Soubra A, Zabell JR, Adejoro O, et al. Effect of perioperative blood transfusion on mortality for major urologic malignancies. Clin Genitourin Cancer 2015;13:e173-81.

12. Cata JP, Wang H, Gottumukkala V, et al. Inflammatory response, immunosuppression, and cancer recurrence after perioperative blood transfusions. Br J Anaesth 2013;110:690-701.

13. Shander A, Hofmann A, Ozawa S, et al. Activity-based costs of blood transfusions in surgical patients at four hospitals. Transfusion 2010;50:753-65.

14. Leahy MF, Trentino KM, May C, et al. Blood use in patients receiving intensive chemotherapy for acute leukemia or hematopoietic stem cell transplantation: the impact of a health system-wide patient blood management program. Transfusion 2017;57:2189-96.

15. DeAndrade D, Waters JH, Triulzi DJ, et al. Very low rate of patient-related adverse events associated with the use of intraoperative cell salvage. Transfusion 2016;56:2768-72.

16. Domen RE. Adverse reactions associated with autologous blood transfusion: evaluation and incidence at a large academic hospital. Transfusion 1998;38:296-300.

17. Linden J. Autologous blood errors and incidents. Transfusion 1994;34:S28.

18. Carless PA, Henry DA, Moxey AJ, et al. Cell salvage for minimising perioperative allogeneic blood transfusion. Cochrane Database Syst Rev 2010;(4):CD001888.

19. Meybohm P, Choorapoikayil S, Wessels A, et al. Washed cell salvage in surgical patients: A review and meta-analysis of prospective randomized trials under PRISMA. Medicine (Baltimore) 2016;95:e4490.

20. Gray CL, Amling CL, Polston GR, et al. Intraoperative cell salvage in radical retropubic prostatectomy. Urology 2001;58:740-5.

21. Ubee SS, Manikandan R, Gudimetla AR, et al. Cost benefits of intraoperative cell salvage in radical cystectomy. 
Indian J Urol 2010;26:196-9.

22. Ubee S, Kumar M, Athmanathan N, et al. Intraoperative red blood cell salvage and autologous transfusion during open radical retropubic prostatectomy: a cost-benefit analysis. Ann R Coll Surg Engl 2011;93:157-61.

23. Davies L, Brown TJ, Haynes S, et al. Cost-effectiveness of cell salvage and alternative methods of minimising perioperative allogeneic blood transfusion: a systematic review and economic model. Health Technol Assess 2006;10:iii-iv, ix-x, 1-210.

24. Waters JH, Donnenberg AD. Blood salvage and cancer surgery: should we do it? Transfusion 2009;49:2016-8.

25. Esper SA, Waters JH. Intra-operative cell salvage: a fresh look at the indications and contraindications. Blood Transfus 2011;9:139-47.

26. Davis M, Sofer M, Gomez-Marin O, et al. The use of cell salvage during radical retropubic prostatectomy: does it influence cancer recurrence? BJU Int 2003;91:474-6.

27. Nieder AM, Carmack AJ, Sved PD, et al. Intraoperative cell salvage during radical prostatectomy is not associated with greater biochemical recurrence rate. Urology 2005;65:730-4.

28. Stoffel JT, Topjian L, Libertino JA. Analysis of peripheral blood for prostate cells after autologous transfusion given during radical prostatectomy. BJU Int 2005;96:313-5.

29. Nieder AM, Manoharan M, Yang Y, et al. Intraoperative cell salvage during radical cystectomy does not affect longterm survival. Urology 2007;69:881-4.

30. MacIvor D, Nelson J, Triulzi D. Impact of intraoperative red blood cell salvage on transfusion requirements and outcomes in radical prostatectomy. Transfusion 2009;49:1431-4.

31. Gorin MA, Eldefrawy A, Manoharan M, et al. Oncologic outcomes following radical prostatectomy with intraoperative cell salvage. World J Urol 2012;30:379-83.

32. Raval JS, Nelson JB, Woldemichael E, et al. Intraoperative cell salvage in radical prostatectomy does not appear to increase long-term biochemical recurrence, metastases, or mortality. Transfusion 2012;52:2590-3.

33. Lyon TD, Ferroni MC, Turner RM 2nd, et al. Short-term Outcomes of Intraoperative Cell Saver Transfusion During Open Partial Nephrectomy. Urology 2015;86:1153-8.

34. Waters JH, Yazer M, Chen YF, et al. Blood salvage and cancer surgery: a meta-analysis of available studies. Transfusion 2012;52:2167-73.

35. Chiusano MA, Finkelstein L, Mene M, et al. Use of predeposited autologous blood plus intraoperative autotransfusion compared with use of predeposited autologous blood alone in radical retropubic prostatectomy. J Am Osteopath Assoc 1996;96:160-4.

36. Gilbert JB, Malkowicz SB, Wein AJ. Cell saver and radical retropubic prostatectomy: analysis of cost-effectiveness. Urology 1995;46:542-4.

37. Waters JH, Lee JS, Klein E, et al. Preoperative autologous donation versus cell salvage in the avoidance of allogeneic transfusion in patients undergoing radical retropubic prostatectomy. Anesth Analg 2004;98:537-42, table of contents.

38. Mohler JL, Armstrong AJ, Bahnson RR, et al. Prostate Cancer, Version 1.2016. J Natl Compr Canc Netw 2016;14:19-30.

39. Dindo D, Demartines N, Clavien PA. Classification of surgical complications: a new proposal with evaluation in a cohort of 6336 patients and results of a survey. Ann Surg 2004;240:205-13.

40. What Blood Products are Supplied - National Product List 2017 (01 November 2017). Available online: https:// www.blood.gov.au/national-product-list

41. Wood E, Bielby L, Hunt R, et al. editors. O116 - Transfusing a Unit of Red Cells - What Does It Really Cost in Australia? 2008 Haematology Society of Australia and New Zealand Annual Scientific Meeting; 2008; Perth, Australia.

42. Leahy MF, Mukhtar S. From blood transfusion to patient blood management: a new paradigm for patient care and cost assessment of blood transfusion practice. Intern Med J 2012;42:332-8.

43. Australian Bureau of Statistics. Consumer price index, hospital and medical services; Australia (A2329041T). Australia: Australian Bureau of Statistics; 2017. Available online: http://www.abs.gov.au/AUSSTATS/abs@.nsf/ DetailsPage/6401.0Jun\%202017?OpenDocument (Table 7).

44. Yaw PB, Sentany M, Link WJ, et al. Tumor cells carried through autotransfusion. Contraindication to intraoperative blood recovery? JAMA 1975;231:490-1.

45. Autologous blood transfusions. Council on Scientific Affairs. JAMA 1986;256:2378-80.

46. NICE. Intraoperative red blood cell salvage during radical prostatectomy or radical cystectomy; Interventional procedures guidance (IPG144): The National Institute for Health and Care Excellence; 2008 (updated April 200801 September 2017). Available online: https://www.nice.org. uk/guidance/ipg258

47. AAGBI. Intra-operative Cell Salvage: The Association of Anaesthetists of Great Britain and Ireland; 2009 (01 September 2017). Available online: https://www.google. com.au/url? sa $=$ t\&rct=j\&q=\&esrc=s\&source=web\&cd=2\& ved=0ahUKEwiQ8sHv65 TXAhUJlJQKHQaACBIQFggt MAE\&url=https\%3A\%2F\%2Fwww.aagbi.org\%2Fsites\%2 
Fdefault\%2Ffiles\%2Fcell_salvage_2009_amended.pdf\&us $\mathrm{g}=\mathrm{AOvVaw39LQkP72BqbtpSzlwpc \_ cm}$

48. National Blood Authority A. Guidance for the provision of intraoperativ cell salvage 2014 (cited 01 September 2017). Available online: https://www.blood.gov.au/system/files/ documents/ics-guidance-march-2014_1.pdf

49. American Association of Blood Banks. Standards for Perioperative Autologous Blood Collection and Administration. 5th ed. Bethesda, MD: Banks AAoB, 2013.

50. Katz E, Gaitini L, Samri M, et al. The use of technologies to decrease peri-operative allogenic blood transfusion: results of practice variation in Israel. Isr Med Assoc J 2001;3:809-12.

51. Schumann R, Mandell MS, Mercaldo N, et al. Anesthesia for liver transplantation in United States academic centers: intraoperative practice. J Clin Anesth 2013;25:542-50.

52. Xie Y, Shen S, Zhang J, et al. The efficacy, safety and cost-effectiveness of intra-operative cell salvage in highbleeding-risk cardiac surgery with cardiopulmonary bypass: a prospective randomized and controlled trial. Int J Med Sci 2015;12:322-8.

53. Kumar N, Chen Y, Zaw AS, et al. Use of intraoperative cell-salvage for autologous blood transfusions in metastatic spine tumour surgery: a systematic review. Lancet Oncol 2014;15:e33-41.

54. Hansen E, Wolff N, Knuechel R, et al. Tumor cells in blood shed from the surgical field. Arch Surg 1995;130:387-93.

55. Catling S, Williams S, Freites O, et al. Use of a leucocyte filter to remove tumour cells from intra-operative cell salvage blood. Anaesthesia 2008;63:1332-8.

56. Wiesel M, Gudemann C, Hoever KH, et al. Separation of urologic tumor cells from red blood cells by the use of a cell-saver and membrane filters. Investig Urol (Berl) 1994;5:244-8.

57. Edelman MJ, Potter P, Mahaffey KG, et al. The potential for reintroduction of tumor cells during intraoperative blood salvage: reduction of risk with use of the RC-400 leukocyte depletion filter. Urology 1996;47:179-81.

58. Wiesel M, Gudemann C, Staehler G. Tumor cell separation by cell saver and membrane filter passage. Infusionstherapie 1991;18:143-4.

59. Osawa T, Nakamura S, Imai T. Intraoperative blood recovery in transurethral resection of prostate (TURP). Nihon Hinyokika Gakkai Zasshi 1992;83:1276-83.

60. Wiesel M, Gudemann C, Staehler G, et al. Separation of urologic tumors cells from Cell Saver blood using a membrane filter. A new method in autotransfusion?
Urologe A 1992;31:182-5.

61. Futamura N, Nakanishi H, Hirose H, et al. The effect of storage on the survival of cancer cells in blood and efficient elimination of contaminating cancer cells by a leukocyte depletion filter. Am Surg 2005;71:585-90.

62. Raval JS, Waters JH, Yazer MH. The impact of suctioning RBCs from a simulated operative site on mechanical fragility and hemolysis. Korean J Hematol 2011;46:31-5.

63. Weiss L. Metastatic inefficiency. Adv Cancer Res 1990;54:159-211.

64. Salsbury AJ. The significance of the circulating cancer cell. Cancer Treat Rev 1975;2:55-72.

65. Mori M, Mimori K, Ueo H, et al. Molecular detection of circulating solid carcinoma cells in the peripheral blood: the concept of early systemic disease. Int J Cancer 1996;68:739-43.

66. Glaves D, Huben RP, Weiss L. Haematogenous dissemination of cells from human renal adenocarcinomas. Br J Cancer 1988;57:32-5.

67. Oefelein MG, Kaul K, Herz B, et al. Molecular detection of prostate epithelial cells from the surgical field and peripheral circulation during radical prostatectomy. J Urol 1996;155:238-42.

68. Yamaguchi K, Takagi Y, Aoki S, et al. Significant detection of circulating cancer cells in the blood by reverse transcriptase-polymerase chain reaction during colorectal cancer resection. Ann Surg 2000;232:58-65.

69. Wang YL, Jiang B, Yin FF, et al. Perioperative Blood Transfusion Promotes Worse Outcomes of Bladder Cancer after Radical Cystectomy: A Systematic Review and MetaAnalysis. PLoS One 2015;10:e0130122.

70. Gardner A, Gibbs N, Evans C, et al. Relative cost of autologous red cell salvage versus allogeneic red cell transfusion during abdominal aortic aneurysm repair. Anaesth Intensive Care 2000;28:646-9.

71. McDonnell NJ, Kennedy D, Long LJ, et al. The development and implementation of an obstetric cell salvage service. Anaesth Intensive Care 2010;38:492-9.

72. Dan M, Liu D, Martos SM, et al. Intra-operative blood salvage in total hip and knee arthroplasty. J Orthop Surg (Hong Kong) 2016;24:204-8.

Cite this article as: Kinnear N, Heijkoop B, Hua L, Hennessey DB, Spernat D. The impact of intra-operative cell salvage during open radical prostatectomy. Transl Androl Urol 2018;7(Suppl 2):S179-S187. doi: 10.21037/tau.2018.04.19 